\title{
Reforma Psiquiátrica: reflexões
}

\author{
Gabriel Figueiredo \\ Departamento de Neuropsiquiatria. Faculdade de Ciências Médicas da Pontifícia Universidade Católica de Campinas
}

Com quase três décadas de atividades em psiquiatria, ocupadas em grande parte com modelos assistenciais em saúde mental, vamos deixar registradas algumas reflexões sobre este momento da reforma psiquiátrica no Brasil.

Existe uma defasagem brasileira em relação ao mundo desenvolvido quanto à assistência psiquiátrica. Isso não é novidade para nenhum psiquiatra, assim como é possível detectar no próprio país descompassos entre Estados e regiões.

Tudo indica que finalmente, neste ano 2000, o Congresso Nacional aprovará o projeto de lei que já tramita há mais de dez anos, ficando ainda a sanção presidencial como última penada.

As entidades representativas da psiquiatria brasileira, assim como as universidades e outros conglomerados científicos, precisam se manifestar durante a discussão e aprovação da matéria. Devem subsidiar o máximo possível os parlamentares, sobretudo os da Comissão de Saúde e Seguridade, que enviarão a dita matéria para votação em plenário por meio do seu relator, um urologista que parece sensível aos problemas da reforma.

Não é exagero subsidiar a Comissão de Saúde e Seguridade sobre a vocação hospitalocêntrica da assistência psiquiátrica em nosso país e desmistificar que ela se deve apenas a questões de mercado. É necessário lembrar que essa vocação foi enraizada como cultura e que tem na caridade e no controle social de área externa suas ramificações principais, além do Tratamento moral, proposto por Pinel, e do Princípio do isolamento, por Esquirol.

Também defender as unidades de internação psiquiátrica, seja em hospital especializado como em hospital geral, é fundamento. No entanto, não devemos nos comprometer com esse mode- lo, considerando-o central. Ele deve ser a última instância assistencial e, naturalmente, um dos espaços acadêmicos de ensino da psiquiatria na interface da assistência, ensino, ética e pesquisa.

Novos modelos assistenciais devem ser estimulados, avaliados na sua eficácia e integrados numa política de reversão do modelo que tradicionalmente teve no hospital psiquiátrico a sua referência maior.

A reforma precisa ser cautelosa, porém corajosa e progressiva. Precisa também obedecer a um planejamento que concilie prioridades com recursos disponíveis e com capacidade de lidar com o imprevisível e o surpreendente.

Evitar radicalizações é uma boa estratégia, sobretudo para os que divergem nos meios, mas concordam com os fins de uma reforma que ofereça aos pacientes e aos profissionais condições de tratamento e trabalho.

Quanto à polêmica da internação compulsória, a questão deve ser resolvida sem perder de vista a necessária conjugação do binômio quadro clínico-cidadania. Isso implica numa exemplar prática psiquiátrica dentro de uma sociedade que privilegia os direitos dos seus cidadãos.

Correspondência:

Gabriel Figueiredo

Departamento de Neuropsiquiatria

Faculdade de Ciências Médicas da Pontifícia Universidade

Católica de Campinas

Rua João Moura, 647, $2^{\circ}$ andar

CEP 05412-811 São Paulo, SP, Brasil 